Konferenssin päätösseremoniassa julkistettiin posterikilpailun voittaja, joka oli Georgy Tarasenko. Samalla palkinnon ansiokkaasta Idäntutkimus-lehdessä julkaistusta artikkelista VIETSin ensimmäistä kertaa järjestämässä artikkelikilpailussa pokkasi Sigrid Kaasik-Krogerus. Hänen voittaja-artikkelinsa "Kuvitellut Pohjoismaat Viron presidenttien puheissa" erottui muista ehdokkaista kilpailua tuomaroineen Arto Mustajoen mukaan uudella näkökulmalla eteläiseen naapuriimme.

Konferenssin antia yhteen vetävässä puheenvuorossaan Venäjän kielen ja kulttuurin professori Sanna Turoma (Tampereen yliopisto) nosti kysymyksen radikaaliin murrokseen tähtäävän tieteellisteknologisen mielikuvituksen, yhteiskunnan teknologisten innovaatioiden ja yhteiskuntatieteiden vuorovaikutuksesta. Hän muistutti, että fantasia- ja tieteiskirjallisuudella oli keskeinen rooli Neuvostoliitossa ja että teknologisten läpimurtojen siemenet kylvetään usein kulttuurialoilla, tieteis- ja fantasiagenreissä esiintyvien vaihtoehtoisten (usein intergalaktisten) maailmoiden muodossa. Venäläistä valtavirran fantasia- ja tieteiskirjallisuutta dominoi kuitenkin tällä hetkellä historiaan kurkottava dystopia tieteellisen ja teknologisen mielikuvituksen jäädessä vähintäänkin taka-alalle. Turoman puheenvuoro avasi kysymyksen jatkopohdinnalle siitä, missä ja miten Venäjällä ja laajemmin Euraasian alueella tulevaisuussuuntautunut tieteellistekno- loginen mielikuvitus kehittyy. Hän ehdotti, että etenkin jälkineuvostoliittolaisen post-imperiaalisen tilan marginaaleissa tapahtuvalla ylirajaisella intellektuaalisella yhteistyöllä on ensiarvoisen tärkeä rooli valtavirran arvokonservatiivisia ja uusliberalistisia käytänteitä kyseenalaistavien positiivisten tieteellisteknologisten utopioiden muodostamisessa.

Nämä pohdinnat veivät ajatukset jouhevasti tulevaisuuteen tutkimusalallamme, ja ensi vuoden konferenssiin, jonka teeman järjestelytoimikuntaa vetävä Anna-Liisa Heusala (Helsingin yliopisto) julkisti tilaisuuden päätteeksi. 2020 Aleksanteri-konferenssi tulee keskittymään globaaliin muuttoliikkeeseen ja Euraasiaan. Haku paneeli- ja esitelmäehdotuksille on auki toukokuun 15. päivään saakka ja hakujulistukseen pääsee tutustumaan tarkemmin konferenssisivuilla https://www.helsinki.fi/en/conferences/ eurasia-and-global-migration.

Joukkoon Aleksanteri-konferenssin 2019 avainpuheenvuoroista ja paneeleista tallennettuja videoita pääsee tutustumaan Aleksanteriinstituutin YouTube-kanavalla, https://www. youtube.com/user/AleksanteriInstitute

Maija Absetz, Bradley Reynolds, Elena Gorbacheva, Juulia Heikkinen, Mika Pylsy \& Saara Ratilainen Kuvat: Elena Gorbacheva ja Niina Into

\title{
VIETSin Idäntutkimus-artikkelipalkinto Sigrid Kaasik-Krogerukselle
}

Venäjän ja Itä-Euroopan tutkimuksen seura VIETS myönsi 18. lokakuuta 2019 Aleksanterikonferenssin päätöstilaisuuden yhteydessä tunnustukset parhaille vuosina 2017-2018 Idäntutkimus-lehdessä julkaistuille Venäjää ja Itä-Euroopan tutkimusta käsitteleville suomenkielisille tieteellisille artikkeleille. Kilpailun tuomarina toimi Venäjän kielen ja kirjallisuuden emeritusprofessori Arto Mustajoki, joka on Venäjän ja Itä-Euroopan tutkimuksen kokenut ja arvostettu asiantuntija. Parhaan artikkelin lisäksi professori Mustajoki antoi erikoismaininnat jännittävimmälle artikkelille, metodologisesti innovatiivisimmalle artikkelille ja tärkeimmälle artikkelille. Palkitut artikkelit löytyvät Idäntutkimus-lehden teemanumeroista Itämeri (2/2017), Vapaus (4/2017) ja Data/menneisyys
(3-4/2018). Julkaisemme ohessa professori Mustajoen perustelut kokonaisuudessaan.

\section{Professori Arto Mustajoen lausunto}

Useimmat arvioimani artikkelit kertovat uusista tutkimustuloksista monitieteiselle suomalaiselle lukijakunnalle. Tämä on tärkeä tehtävä, sillä se auttaa tutkijoita avartamaan omia näkemyksiään ja saamaan näin virikkeitä myös omaan tutkimukseensa riippumatta sen konkreettisesta aihepiiristä. Tekstin sopeuttamiseen lukijoiden mukaan käytetään kahta tapaa: tutkittavaa aihetta taustoitetaan tavallista laajemmin ja asioiden käsittelyssä vältetään suppeiden tutkimusalojen omaa jargonia. Mielestäni kirjoittajat ovat onnistuneet tässä useimmissa tapauksissa erin- 
omaisesti. Kunnia tästä kuuluu osittain tietysti lehden toimittajille.

Artikkelien yleinen taso oli hyvin korkea, sanoisin ilahduttavan korkea. Tämä kertoo suomalaisen Venäjä-tutkimuksen laajuudesta ja laadukkuudesta. Koska lähes kaikki artikkelit edustivat sellaista alaa, jota en ole muuten seurannut, minulla ei ole kompetenssia arvioida niiden tieteellistä antia kyseisen tieteenalan näkökulmasta. Oikeastaan minulla oli vaikeuksia edes määritellä, mistä tieteenalasta kulloinkin oli kysymys - mutta ajattelin, onko sillä niin väliä. Niinpä yritin kiinnittää huomiota artikkelin tarjoaman näkökulman tuoreuteen ja siihen, mitä uutta tietoa se tuo laajempaan tietoisuuteen.

Ennen kuin perustelen lopullista valintaani, haluaisin antaa kunniamaininnan muutamalle muulle artikkelille. Mielestäni jännittävin artikkeli oli Mia Öhmanin artikkeli "Tarkovskin vapaus". Artikkeli tempaa lukijan mukaansa melkein dekkarin tavoin. Murhaajaa ei yritetä selvittää, vaan kyse on jostain paljon suuremmasta: mitä taiteilijalle merkitsee luomisen vapaus? Neuvostoaika tuo tapahtumien kulkuun oman värinsä. Paineita ei ehkä tule virkavallan taholta, mutta niitä luovat vallitsevat taiteen sisäiset muodit, media ja kollegat. Samanlaista omien rajojensa pohtimista kohtaa taiteilija kaikissa olosuhteissa.

Metodisesti innovatiivisin artikkeli oli Mihail Sokolovin, Nadežda Sokolovan ja Maria Safonovan big data -analyysi pietarilaisten lukumieltymyksistä. Artikkeli perustuu laajan data-aineiston monipuoliseen käsittelyyn. Kirjoittajat itsekin myöntävät, että kyseessä on metodologinen kokeilu. Aineistona on pietarilaisten kirjastonkäyttäjien kirjastokorttien jättämät jäljet, eli siis se mitä he lukevat. Kun dataan liitetään tiettyjä taustamuuttujia, kuten koulutustaso, saadaan jännittäviä tietoja käyttäjien lukutottumuksista. Artikkelin erityisenä ansiona on metodin kriittinen arvio, eli mitä sen avulla saadaan selville ja mitä ei, mitä mahdollisia virhelähteitä on olemassa jne. Uskoisin, että tämäntapaisia artikkeleita tullaan näkemään enemmänkin Idäntutkimus-lehden sivuilla. Big data -analyysi ei korvaa aiemmin käytettyjä metodeja, mutta täydentää niitä mielenkiintoisella tavalla.

Tärkein arvioimani artikkeli oli Maiju Lehdon artikkeli "Ukrainan sota ja taistelu menneisyydestä". Artikkeli avaa täysin uudenlaisen näkökulman Ukrainan sotaan ja taisteluun menneisyydestä. Se perustuu melko pieneen aineistoon, kahdeksan rintamalla taistelleen ukrainalaissotilaan haastatteluun, mutta siitä huolimatta artikkeli avaa täysin uudenlaisen näkökulman Ukrainan konfliktiin. Kulttuurisen muistitutkimuksen metodein paljastetaan, että aseellisen vastakkainasettelun juuret ovat paljon kauempana kuin viime vuosien kielipolitiikassa. Haastattelut auttavat näkemään, mistä ukrainalaisessa patriotismissa ja kansallisen identiteetin rakentamisessa todellisuudessa onkaan kysymys.

Sitten päästäänkin parhaimman artikkelin valintaan. Paras Idäntutkimuksessa vuosina 2017-2018 julkaistu tieteellinen artikkeli on mielestäni Sigrid Kaasik-Krogeruksen "Kuvitellut Pohjoismaat Viron presidenttien puheissa". Idäntutkimus-lehden Itämeri-teemanumerossa (2/2017) julkaistussa artikkelissa pohditaan, miten Viro asemoi itseään tämän päivän maailmassa. Aikaisemman Baltia-narratiivin rinnalle on tullut tarve osoittaa, että Viro on osa Pohjoismaita. Artikkelissa tutkija ei lähde vertailemaan eri presidenttejä keskenään, vaan tarkastelee presidentti-instituutiota kokonaisuudessaan. Virolaiset poliitikot ovat itse huomanneet, että nykyään Virosta puhutaan usein "uutena Pohjoismaana". Se on maan uusi "suuri narratiivi". Artikkeli piirtää lukijan eteen uudenlaisen kuvan eteläisestä naapuristamme. Tämä auttaa meitä käymään hedelmällistä vuoropuhelua virolaisten kanssa. Tällaisen lähestymistavan soisi olevan laajemminkin esillä myös suomalaisessa Venäjän ja Itä-Euroopan tutkimuksessa.

\section{Kutsu keskustelemaan muuttoliikkeistä ja ylirajaisesta vuorovaikutuksesta}

Kuluvana vuonna 20. kerran järjestettävä Aleksanteri-konferenssi tarkastelee globaaleja ja ylirajaisia muuttoliikkeitä, yhteisöjä ja kulttuurin virtauksia laajasta näkökulmasta. Konferenssin maantieteellinen alue ulottuu entisen Neuvos- toliiton itäisistä ja eteläisistä alueista Keski- ja Itä-Eurooppaan. Konferenssissa tarkastellaan muuttoliikkeitä ja maahanmuuttajien toimijuutta sosiaalisissa, poliittisissa, kulttuurisissa ja taloudellisissa yhteyksissä, sekä erityisesti 